\title{
O Termalismo Tem Lugar na Reumatologia nos Dias Atuais?
}

\section{Does Thermalism Have a Role in Today's Rheumatology?}

\author{
Rodrigo Montandon Esteves Pires ${ }^{(1)}$
}

Empregamos a designação termalismo e crenoterapia, quando nos referimos ao conjunto de atividades terapêuticas desenvolvidas no espaço de um estabelecimento balneário e que tem como agente terapêutico a água termal, com propriedades físico-químicas distintas das águas comuns. ${ }^{(1)}$

Foram encontradas citações do uso destas águas desde a antiguidade, entre os turcos e gregos. As obras de Homero descrevem situações sugestivas de banhos termais, mas foi o povo romano que as popularizou como fonte de cura e prazer. Durante a Idade Média, esta prática foi alvo de hostilidade por parte da Igreja Católica, sendo considerada infame e um atentado contra a castidade, sendo abandonada. ${ }^{(1,2)}$

Após o período medieval, a Igreja reformulou sua posição, passando o clero a organizar peregrinações até às fontes, sobretudo na França, o que resultou na abertura de estabelecimentos termais, onde as águas eram consideradas santas e curativas. Nestes locais surgiram povoações e lugares de culto, inicialmente destinados apenas à aristocracia e à burguesia, que os procuravam em busca de um milagre, ou apenas para mudança de ares ${ }^{(1)}$. As termas eram recomendadas como um epítome da natureza salutar e foram assim difundidas, com maior ênfase na saúde ou na doença, de acordo com o discurso médico, os interesses turísticos ou aos grupos a quem se dirigiam.

No século XIX, por motivos econômicos e terapêuticos, desenvolveu-se na França o termalismo, com a criação de uma especialidade chamada hidrologia médica (crenologia), que teria a função de pesquisar e desenvolver métodos de tratamento com as águas termais. O crenologista seria o responsável pelo balneário.

Nos periódicos editados pela Academia Real de Medicina Brasileira, no século XIX, as primeiras notícias sobre águas minerais referiam-se às fontes termais de Goiás e à utilização da sua água para o tratamento da morféia, em 1839. A partir da segunda metade do século, com o desenvolvimento da química e da própria medicina, iniciou-se pesquisas sobre suas propriedades terapêuticas.
No Brasil, a primeira de várias teses sobre este tema foi defendida na Escola de Medicina e Cirurgia do Rio de Janeiro, em 1841, por António Maria de Miranda Castro ${ }^{(1)}$. O autor falava das potencialidades das águas e da necessidade do Brasil investir neste campo, à semelhança do que se passava na Europa, onde as águas minerais serviam de meio sanitário e fundo precioso de interesse e prosperidade. Existem descrições de pesquisas realizadas por médicos crenólogos de Poços de Caldas, Araxá, Caxambu, Águas de São Pedro, Águas de Lindóia e também por Faculdades de Medicina de Belo Horizonte, São Paulo, Rio de Janeiro, Curitiba e Porto Alegre. Com a descoberta de novos medicamentos, novos conceitos e práticas médicas e pelo mecanismo de ação impreciso das águas, a partir da segunda metade do século XX, diminuíram no Brasil as pesquisas e as práticas crenoterápicas.

Os primeiros trabalhos que encontramos na literatura indexada são da década de 50 , e a maior parte deles é da década de 70 e 80, desenvolvidos principalmente na França, seguido pela Itália, Rússia, Espanha e Portugal. Relatam-se bons resultados, mas a metodologia é pobre. Várias doenças foram incluídas nestes trabalhos e dentro da reumatologia são citadas gota, artrites, lombalgia, cervicalgia, osteoartrite e síndrome miofascial ${ }^{(3-5)}$.

A composição das águas termais varia conforme a região e o local de extração e inclui minerais que formam vários compostos como: sulfureto ácido de sódio, sulfureto neutro de sódio, hiposulfito de sódio, sulfato de sódio, carbonato ácido de amônio, carbonato ácido de alumínio, nitrato de potássio, fosfato de ferro, arseniato ácido de potássio, sulfato de cálcio, sulfato de magnésio, ácido silícico, carbonato ácido de cálcio, carbonato ácido de sódio, carbonato ácido de magnésio, cloreto de sódio, fosfato ácido de alumínio, sulfato de potássio, fosfato ácido de potássio, ácido carbónico dissolvido e oxigênio dissolvido. Algumas destas águas também são radioativas por atravessarem jazidas de rádio e tório, antes de aflorar, e ter estes elementos dissolvidos na sua composição ${ }^{(7,8)}$. Essa heterogenicidade leva

Recebido em 07/07/06. Aprovado, após revisão, em 15/08/06.

1. Médico Reumatologista de Araxá (MG), ex-residente do Serviço de Reumatologia do Hospital da PUC Campinas

Endereço para correspondência: Rodrigo Montandon Esteves Pires, Rua Dom José Gaspar, 311, apto. 102, Centro, Araxá, CEP 38183-188, MG, Brasil, telefone (34) 3661-8090, e-mail: rodrigoegisele@hotmail.com 
a pHs e propriedades físico-químicas diferentes, o que limita a realização de experimentos científicos.

O mecanismo de ação ainda não está claro, mas considera-se que a melhora do paciente se baseie na vaso-dilatação periférica pelas imersões em águas termais quentes, restabelecimento do equilíbrio ácido-básico e mineral, ação sedativa levando a vasodilatação arterial e melhora da função cardiovascular, melhora da secreção gastro-pancreática, do peristaltismo intestinal, da função hepática com maior secreção de bile e da função renal como diurético ${ }^{(9,10)}$.

Dentro da reumatologia as águas são usadas para ingestão, hidroterapia, reeducação postural e relaxamento muscular. Compressas com lama sulfurosa são usadas em artrites e osteo$\operatorname{artrites}^{(5-10,11)}$

Pelo que se observa na história do termalismo, existe uma

\section{REFERÊNCIAS}

1. Quintela MM: Saberes e práticas termais: uma perspectiva comparada em Portugal (Termas de S. Pedro do Sul) e no Brasil (Caldas da Imperatriz). Hist Cien Sau 1:239-260, 2004.

2. Mellilo L: Termalismo nel mondo antico. Med Sec 7: 461-483, 1995.

3. Laroche C: Lê suivi d'une cohorte de 3000 curistes thermaux pendant trois ans par lê service national du controle medicai du regime general. Buli Acad Natle 171: 869-886, 1987.

4. Françon J: Kinésithérapie, physiothérapie et crénothérapie dans lês discarthroses lombaires et lês lombalgies. Rev Prat 22: 30713077, 1972.

5. Quintela MM: Turismo e reumatismo: uma etnografia das experiências termais nas Termas de São Pedro do Sul. Etnográf relação ambígua entre turismo e prática terapêutica. Por vezes introduz-se o turismo para justificar a prática termal e o desenvolvimento econômico e em outros momentos defendem-se as estâncias termais como locais apenas para doentes. No entanto, na última década, o processo de afirmação do turismo de saúde, no qual é integrado o termalismo, tem vindo a mediar esta relação, pela mudança de ênfase da doença para a saúde, da cura para a prevenção(1-5).

Faltam dados científicos consistentes sobre a eficácia do termalismo e trabalhos com metodologia precisa poderão no futuro esclarecê-la, porém, com base nos relatos de satisfação, bem estar e melhora subjetiva de vários pacientes que freqüentam balneários, pode-se ter na crenoterapia uma aliada da reumatologia, ajudando no restabelecimento da qualidade de vida do paciente reumatológico, tão valorizado na medicina atual.

2: 359-374, 2001.

6. Grassi M, Lazzari S, Sottili S: Crenotherapy in sports medicine. Clin Ter 147: 645-652, 1996.

7. Magalhães MC: A estância de Araxá. Soe Arg Hidra Clim 1: 4149, 1945.

8. Accorinti J: Caracterización cromatográfica de subfracciones antimicrobianas dei água Del volcán Capahue. Acta Bioquim Clin Latinoam 28: 425-431, 1994.

9. Vanzuela AM: Fatigue of life aging. Balneology cures. Ann RAcad Nac Med 120: 355-369, 2003.

10. Demogeot F: Lês indications privilégiées de Ia crénothérapie, sés contre-indications. Phlébo 35: 581-586, 1982.

11. Martin M, Gottardo MT: Crenotherapy. Soins Chir 52: 76-79, 1987. 